Volume 4 • Nomor $1 \cdot$ Oktober 2020

Pege (Hal.) : $62-78$

(C) Universitas Pamulang

JL.Surya Kencana No.1 Pamulang, Tangerang Selatan - Banten

website. :

Telp. (021) 7412566, Fax (021) 7412491

http://www.openjournal.unpam.ac.id/index.php/JPK

Email :jurnalmarketing.unpam@gmail.com

\title{
Store Atmosphere Pengaruhnya Terhadap Minat Beli Kosumen Pada Toko Roti Breadlife Cabang Bintaro Exchange
}

\author{
Bunga Astra Gracia ${ }^{1}$; Kris Dipayanti ${ }^{2}$ \\ Universitas Pamulang, dosen01016@unpam.ac.id
}

\begin{abstract}
Abstrak Penelitian ini bertujuan untuk mengetahui pengaruh store atmosphere terhadap minat beli konsumen pada PT. Dunia Makmur Jaya (BreadLife) Tbk cabang Bintaro Exchange. Jenis penelitian adalah penelitian assosiatif kuantitatif dengan menggunakan kuesioner sebagai metode pengumpulan data disebarkan kepada konsumen Toko Roti Breadlife cabang Bintaro Exchange sebagai obyek penelitian.Teknik sampel menggunakan rumus slovin, tingkat kesalahan $10 \%$ diperoleh sampel penelitian 96 responden.Teknik Analisis Data dengan uji validitas, uji reliabilitas, uji koefisien korelasi, uji regresi linier sederhana, uji koefisien determinasi, Uji Hipotesismenggunakan SPSS21. Hasil penelitianmenunjukkan terdapat pengaruh positif dan signifikan antara store atmosphereterhadap minat beli konsumendenganpersamaan regresi $Y=9,885+0,758 X$. Store atmospharemempengaruhi minat beli sebesar $73,2 \%$ dan sisanya dipengaruhi oleh variabel lain. Uji t sebesar 4,790 >1,6612, dan dengan nilai signifikansi $0,000<0,1$, artinya $\mathrm{H} 0$ ditolak dan $\mathrm{H} 1$ diterima, terdapat pengaruh yang positif dan signifikan antara store atmosphrereterhadap minat beli.
\end{abstract}

Kata kunci : Store Atmosphere; minat beli.

Abstract. This research aims to determine the influence of store atmosphere againts the interest of buying consumers in PT. Dunia Makmur Jaya (BreadLife) Tbk branch of Bintaro Exchange. The research type is quantitative associative research with questionnaires as a method of collecting data that share to the customers of Breadlife Bakery branch Bintaro Exchange as research object. With Slovin formulas as The sample technique, an error rate of $10 \%$ obtained sample research of 96 respondents. The analysis data techniques uses validity tests, reliability tests, correlation coefficient tests, simple linear regression tests, coefficient of determination testing, hypothesis testing with SPSS 21 programme. The results showed there was a positive and significant influence between store atmosphere againts the interest of buying with regression equations $Y=9,885+0.5,758 X$. Store Atmosphare affects the interest of buying by $73.2 \%$ and other variables affects the interest of buying by $26.8 \%$. The $T$ test is $4.790>1.6612$, and with a significance value of $0.000<0.1$, meaning $H_{0}$ rejected and $H_{1}$ accepted, there is a positive and significant influence between store atmosphrere against the interest of buying.

Keyword : Store Atmosphere; Interest of Buying 


\section{A. PENDAHULUAN}

Dengan semakin berkembang teknologi dan arus informasi menyebabkan persaingan bisnis semakin ketat. Perkembangan bisnis yang semakin meningkat ditandai dengan semakin banyak industri yang tumbuh dan berkembang baik industri skala kecil maupun besar. Dengan meningkatnya permintaan pasar membuat para pelaku bisnis untuk terus berinovasi dan berkreasi dalam rangka menarik minat beli konsumen. Selain itu para pelaku bisnis harus quick response in reading bussiness opportunities.

Seiring dengan meningkatnya konsumsi masyarakat di Indonesia, Industri makanan dan minuman mengalami peningkatan yang cukup signifikan. Hal ini menyebabkan timbulnya persaingan kompetitif antar para pelaku bisnis, terutama bisnis kuliner. Agar dapat bertahan dan bisa memenangkan persaingan, para pelaku bisnis terus melakukan inovasi, mengembangjkan strategi bagi usaha yang dijalaninya. Salah satu strategi yang dilakukan pengusaha adalah dengan memperhatikan faktor store atmosphere meliputi exterior, general interior, store layout dan interior display yang bisa mempengaruhi mood (suasana hati) kosnumen yang berkunjung ke Toko dan dapat membangkitkan minat beli konsumen sehingga akhirnya melakukan pembelian. Store atmosphere berperan penting dalam rangka menarik minat konsumen untuk berkunjung dengan cara memberikan fasilitasi kemudahan dan tampilan ruangan yang nyaman dan unik sehingga konsumen merasa betah dan nyaman.

Kotler dan Amstrong (2015:384) berpendapat "The store atmosphere is another important element in the reseller's product. Retailers want to create a unique store experience, one that suits the target market and moves customer to buy". Berman and Evan yang dialih bahasakan Lina Salim (2014:528) menyatakan bahwa mengemukakan "store atmosphere included interior, exterior, comfortness, air sirculation, services, music, staff uniform, traffic flow in store, display product, etc to create consumers interest and make them eager to buy the product".

Dari pengertian diatas dapat disimpulkan bahwa store atmosphere memegang peranan penting dalam upaya agar konsumen terus menerus berkunjung ke toko tersebut dan bukan toko pesaing. Untuk itu perlu adanya inovasi dan rancangan atau dekorasi yang baru dan unik dalam mendesain toko supaya lebih dikenal oleh masyarakat secara luas. Dengan semakin banyaknya bermunculan perusahaan-perusahaan kuliner baru, hal ini menjadi sebuah tantangan bagi pengusaha kuliner untuk mengembangkan strategi dalam memenangkan persaingan. Dan store armosphere merupakan salah satu strategi yang digunakan sebagai siasat dalam persaingan dan upaya untuk dapat menarik minat beli konsumen.

Minat beli konsumen menurut Simamora dikutip oleh Veronika (2016:21) adalah "sesuatu yang pribadi dan berhubungan dengan sikap, individu yang berminat terhadap suatu obyek akan mempunyai kekuatan atau dorongan untukmelakukan serangkaian tingkah laku untuk mendekati atau mendapatkan obyek tersebut".

PT. Dunia Makmur Jaya (BreadLife) Tbk cabang Bintaro Exchange, sebagai salah satu perusahaan yang bergerak di bidang produksi bakery dan pastry di dirikan pada tahun 2010 di indonesia, memiliki misi untuk menjadi perusahaan nomor 1 dalam bidang bakery dan pastry dengan membentuk jaringan retail waralaba yang unggul dalam persaingan global dengan karyawan yang penuh semangat dan berdisiplinan tinggi dalam bekerja dan dan melakukan pekerjaannya dengan efektif dan efisien, sehingga akhirnya dapat memperlihatkan kinerja tinggi dalam rangka mewujudkan misi \& tujuan yang telah di tetapkan oleh perusahaan. PT. DUNIA MAKMUR JAYA (Breadlife) beralamat di Jl. Meruya Utara No.128, Kembangan, Jakarta Barat. PT DUNIA MAKMUR JAYA (Breadlife) memiliki cabang-cabang yang telah di sebar di 19 kota-kota besar di wilayah Indonesia. 
Store atmosphere dari Breadlife cabang Bintaro Exchange terbagi menjadi 4 bagian diantaranya exterior, general interior, store layout dan interior display. Untuk bagian exterior, Breadlife menggunakan tampilan sederhana dimana konsumen dapat melihat secara langsung produk roti yang ditawarkan, ukuran toko yang relatif kecil sehingga membuat konsumen kurang leluasa dalam bergerak. Untuk general interior, desain warna dinding putih dan penampilan logo dengan dasar merah dirasakan kurang menarik dimana logo yang ditampilkan berukuran kurang besar. Pencahayaan didalam toko dirasakan masih kurang terang. Apabila dibandingkan dengan Toko Roti lain yang lokasinya tak jauh dari toko Breadlife dimana pencahayaan toko melalui lampu gantung berwarna putih membuat toko menjadi lebih terang selain itu lampu gantung artistik membuat tampilan toko menjadi lebih menarik

Untuk Store Layout, Peletakan mesin kasir toko Breadlife yang didepan jalur keluar dirasakan kurang efektif karena pelanggan diharuskan antri diluar toko tanpa ada tali pembatas sehingga terkadang menggangu pelanggan lain yang lewat didepan toko. Hal ini berbanding terbalik dengan toko Breadtalk dimana antrian pelanggan ada didalam toko sehingga tidak menggangu pelanggan lain yang lewat. Penataan Produk Roti Breadlife dalam etalase dirasakan kurang menarik dengan pencahayaan yang kurang. Produk roti yang ditawarkan juga kurang bervariasi. Dibagianinterior display, Breadlife menambahkan poster produk roti yang ditawarkan yang berfungsi sebagai alat promosi, akan tetapi tampilan poster tersebut diarasakan masih sederhana dan kurang menarik. Breadtalk menampilkan poster produk roti dengan tampilan yang menarik dan membuat pelanggan ingin mencoba produk roti tersebut.

Tampilan Store atmosphere yang dirasakan kurang menarik membuat minta beli konsumen kurang. Kurang bervariasinya produk yang ditawarkan membuat minat transaksional konsumen menurun, dan minat referensial (Minat untuk merekomendasikan produk kepada orang lain) berkurang. Dan ini berdampak pada tingkat penjualan yang menurun seperti yang terlihat pada tabel 1.1 berikut ini :

Tabel 1.1

Data Penjualan PT. Dunia Makmur Jaya TBK. (Breadlife) Cabang Bintaro Exchange Tahun 2018

\begin{tabular}{|c|c|c|c|c|}
\hline No & Bulan & $\begin{array}{c}\text { Target } \\
\text { Perusahaan }\end{array}$ & Pencapaian & $\begin{array}{c}\text { Presentase } \\
\text { Pencapaian }\end{array}$ \\
\hline 1 & Januari & 300.000 .000 & 200.000 .000 & $66 \%$ \\
\hline 2 & Februari & 310.000 .000 & 210.000 .000 & $67 \%$ \\
\hline 3 & Maret & 260.000 .000 & 205.000 .000 & $78 \%$ \\
\hline 4 & April & 270.000 .000 & 210.000 .000 & $77 \%$ \\
\hline 5 & Mei & 280.000 .000 & 220.000 .000 & $78 \%$ \\
\hline 6 & Juni & 285.000 .000 & 230.000 .000 & $80 \%$ \\
\hline 7 & Juli & 290.000 .000 & 222.000 .000 & $76 \%$ \\
\hline 8 & Agustus & 280.000 .000 & 205.000 .000 & $73 \%$ \\
\hline 9 & September & 290.000 .000 & 220.000 .000 & $75 \%$ \\
\hline 10 & Oktober & 295.000 .000 & 225.000 .000 & $76 \%$ \\
\hline 11 & November & 295.000 .000 & 215.000 .000 & $72 \%$ \\
\hline 12 & Desember & 300.000 .000 & 245.000 .000 & $81 \%$ \\
\hline \multicolumn{2}{|c|}{ Total } & 3.455 .000 .000 & 2.607 .000 .000 & $75 \%$ \\
\hline
\end{tabular}

Sumber : Data Penjualan di PT. Dunia Makmur Jaya Tbk Cabang Bintaro Exchange Tahun 2018. 
Dari data tabel 1.1. diatas ketahui bahwa tingkat penjualan roti Breadlife di tahun 2018 mengalami fluktuasi dan belum mencapai target yang diharapkan, seperti pada bulan Oktober prosentase pencapaian target penjualan sebesar $76 \%$, menurun dibulan November menjadi sebesar $72 \%$ dan meningkat di bulan Desember prosentase pencapaian hanya sebesar $81 \%$. Menurunnya tingkat penjualan disebabkan minat beli konsumen yang berkurang. minat preferensial juga dirasakan masih kurang, selain itu minat eksploratif konsumen juga dirasakan kurang dimana konsumen jarang mencari tahu tentang produk yang diminati.

Berdasarkan pada penjelasan latar belakang permasalahan di atas, untuk itu penulis merasa tertarik mengambil tema ini dan memilih judul sebagai berikut :"Store Atmosphere pengaruhnya terhadap Minat Beli Konsumen pada Toko Roti Breadlife cabang Bintaro Exchange".

\section{Rumusan Masalah}

Rumusan masalah pada penelitian ini adalah bagaimana pengaruh Store Atmosphere (store exterior, general interior, store layout dan interior display) terhadap Minat Beli Konsumen pada Toko Roti Breadlife cabang Bintaro Exchange?

\section{Tujuan Penelitian}

a. Untuk mengetahui bagaimana Store Atmosphere pada Toko Roti Breadlife cabang Bintaro Exchange

b. Untuk mengetahui bagaimana Minat beli Konsumen pada Toko Roti Breaflife cabang Bintaro Exchange

c. Untuk mengetahui pengaruh Store Atmosphere terhadap Minat beli Konsumen pada Toko Roti Breaflife cabang Bintaro Exchange

\section{B. KAJIAN LITERATUR}

Dalam upaya menjalankan perusahaan, pemasaran memegang peranan sangat penting. Kegiatan dalam bidang pemasaran mencakup sales, menentukan market segmentation, menentukan harga, promosi yang akan dilakukan, saluran distribusi dan lainlain. Kotler dan Armstrong (2014:27) berpendapat "marketing is a value creation process for customers as well as building strong relationships with customers, and aims to capture that value from customers in returns". Every company must set the marketing strategy and target market. Marketing activities start from producing a product until the product is received by the customer. All activities conducted in marketing are determine the products, markets, prices, and promotions. The element of marketing mix on the product is different from the marketing mix on the service because the service has different characteristics from the product, such as intangibility, inspirability, variability, and perishability.

Marketing Mix menurut Kotler \& Armstrong (2015: 76) yaitu "The marketing mix is the set of tactical marketing tools that the firm blends to produce the response it wants in the target market" artinya perangkat alat pemasaranyang dipadupadankan untuk memproses tanggapan yang diinginkan oleh target pasar. Menurut Jerome Mc.Charty dikutip oleh Kotler dan Keller (2016:48) "the element of marketing mix including Product, Price, Place, Promotion, People, Physical Evidence,Process".

\section{Store Atmosphere}

Seperti yang dikemukakan Levy dan Weitz dalam Utami (2017:63) "store atmosphere is combination of store characteristic including architecture, display, signs, color, lighting, temperature, music, aroma that create image in customer mind." Kotler dan Amstrong (2015:384) menyatakan "The store atmosphere is another important element in the 
reseller's product. Retailers want to create a unique store experience, one that suits the target market and moves customer to buy". Sedangkan menurut Berman dan Evan yang dialih bahasakan Lina Salim (2014:528) mengemukakan store atmosphere included interior, exterior, comfortness, air sirculation, services, music, staff uniform, traffic flow in store, display product, etc to create consumers interest and make them eager to buy the product"

Menurut Berman dan Evans (2017:465) Store atmosphere meliputi Exterior, general interior, store layout dan interior display.

a. Exterior (bagian depan toko)

Exterior merupakan bagian luar (facade) dari sebuah toko. Untuk itu harus dapat memberikan kesan menarik sehingga konsumen tertarik dan mau berkunjung. Bagian terluar ini harus dapat meciptakan trust and goodwill serta mempengaruhi minat beli konsumen. Adapun dimensinya yaitu entrance, visibility of store boards, Store area and building height, store uniqueness, parking facilities.

b. General Interior (Bagian dalam toko)

Store Interior design dirancang dalam rangka memaksimalkan visual merchandising. The best display adalah display yang menarik perhatian konsumen dan membuat konsumen dapat memperhatikan, mengecek dan memilih barang tersebut lalu membeli produk/service yang ditawarkan. Dimensi dari General Interior adalah lighting, music, cleanliness, temperature, aroma

c. Store Layout (Tata letak toko)

Store management harus memiliki wacana menentukan lokasi dan fasilitas toko. Store management dapat memanfaatkan ruang yang ada didalam toko se-efektif mungkin. Adapun dimensi Store Layout ialah space alocation, Classification product, traffic flow in store, arrangement store space, store mapping dan product arrangement.

d. Interior display (Dekorasi dalam toko)

Interior Display bertujuan memberikan informasi mengenai produk kepada konsumen serta menambahkan store atmosphere, sehingga dapat meningkatkan penjualan dan laba. Dimensi Interior display yaitu theme setting diaplay, assortment display, rack and cases display, ensemble display, card display, signs and posters.

\section{Minat Beli Konsumen}

Menurut Sciffman dan Kanuk dalam Adi (2015:36) "Buying interest is the attitude of consumers who are pleased with some object and then in various way try to buy it or try to get it with sacrifies. Sedangkan minat beli menurut Simamora yang dikutip oleh Veronika (2016:21) adalah "sesuatu yang pribadi dan berhubungan dengan sikap, individu yang berminat terhadap suatu obyek mempunyai kekuatan atau dorongan untuk melakukan serangkaian tingkah laku untuk mendekati atau mendapatkan obyek tersebut".

Langkah-langkah konsumen dalam menentukan buying interest lalu melakukan pembelian produk/ service yang ditawarkan, sesuai dengan konsep AIDA yang dikembangkan Kotler dan Keller (2016:568), yaitu: Attention, Interest, Desire, Actions (AIDA). Dan indikator Minat beli menurut Ferdinand yang dikutip oleh Veronika (2016:24) adalah sebagai berikut:

a. Minat transaksional (Transactional Interest)

Transactional interest is the tendency of a person to buy a particular product. Consumers already have an interest in purchasing a particular product that consumers want.

b. Minat referensial (Referetial Interest)

Referetial interest is the tendency to refer certain products to others. Consumers have an interest in purchasing certain products and advising the people around them to purchase the products. 
c. Minat preferensial (Preferetial Interest)

Preferential interest is an interest that describes someone behavior that has a primary preference of the product. This preference only can be replaced if there is error with their product preference.

d. Minat eksploratif (Explorative Interest)

Explorative interest is the consumers behavior that always try to looking for the information of the product that he/she is interested in and also try to looking for others information about the product.

Berdasarkan hasil penelitian sebelumnya dimana terdapat gap, maka hipotesis dari riset ini adalah :

$\mathrm{H}_{\mathrm{o}}$ : Diduga tidak terdapat pengaruh yang positif dan signifikan antara Store Atmosphere terhadap Minat Beli Konsumen pada Toko Roti Breadlife Cabang Bintaro Exchange.

$\mathrm{H}_{1}$ : Diduga terdapat pengaruh positif dan signifikan antara Store Atmosphere terhadap Minat Beli Konsumen pada Toko Roti Breadlife Cabang Bintaro Exchange

STORE ATMOSPHERE PENGARUHNYA TERHADAP MINAT BELI KONSUMEN PADA TOKO ROTI BREADLIFE CABANG BINTARO EXCHANGE

\begin{tabular}{|c|c|c|}
\hline $\begin{array}{l}\text { Store Atmosphere }(\mathrm{X}) \\
\text { 1. Exterior } \\
\text { 2. General Interior } \\
\text { 3. Store Layout } \\
\text { 4. Interior Display } \\
\text { Sumber : Berman dan Evans } \\
(2017: 465)\end{array}$ & $\mathrm{H} 1$ & $\begin{array}{l}\text { Minat Beli Konsumen }(\mathrm{Y}) \\
\text { 1. Minat Transaksional } \\
\text { 2. Minat Referensial } \\
\text { 3. Minat Preferensial } \\
\text { 4. Minat Eksploratif } \\
\text { Sumber: Ferdinand dalam Veronika } \\
(2016: 24)\end{array}$ \\
\hline
\end{tabular}

Gambar 1. Kerangka Berpikir

\section{B. METODOLOGI PENELITIAN}

Penelitian dilakukan pada PT. Dunia Makmur Jaya Tbk (Breadlife) cabang Bintaro Exchange, Tangerang Selatan.Subyek penelitian merupakan konsumen yang melakukan pembelian pada Toko Roti Breadlife cabang Bintaro Exchange.Penelitian ini dilakukan untuk mengetahui pengaruh Store Atmosphere terhadap Minat Beli Konsumen.

Metode penelitian assosiatif dengan pendekatan kuantitatif sebagai metode penelitian yang digunakan dalam penelitian ini. Associative research aims to find out the relationship of two or more variables. In this study, a theory can be established to explain, predict and control a symptom, which in this case is used to explain the effect of store atmosphere on interest of buying. Populasi dalam penelitian merupakan konsumen yang melakukan pembelian pada Toko Roti Breadlife cabang Bintaro Exchange dengan jumlah populasisebanyak 2600 konsumen dan periode pengumpulan data dari bulan Januari - Maret 2020 .

Sampling Technique untuk penentuan sampel yangdigunakan dalam penelitian ini dengan Proporsional random sampling. Proportional random sampling is the sample selected in randomly and proportionally by means of proportionality. In order to obtain a representative sample, the authors took multiple samples with the same odds using the slovin formula with a $10 \%$ error rate. Collection data method that used in this research is library research and 
field research. Sumber data dalam penelitian ini adalah sumber primer dan sumber sekunder supaya memperoleh datayang relevan, akurat dan reliabel.

\section{HASIL DAN PEMBAHASAN}

1. Karakteristik Responden

Obyek dalam riset ini merupakan konsumen/ pelanggan yang membeli roti di Toko Roti Breadlife cabang Bintaro Exchange. Dari sampel sebanyak 96 responden diperoleh data responden yang dapat dikelompokkan sebagai berikut ini :

\section{a. Responden Menurut Jenis Kelamin}

\section{Karakteristik Responden Berdasarkan Jenis Kelamin}

Jenis_kelamin

\begin{tabular}{|rl|r|r|r|r|}
\hline & & Frequency & Percent & Valid Percent & Cumulative Percent \\
\hline \multirow{2}{*}{ Valid } & Pria & 34 & 35.4 & 35.4 & 35.4 \\
& Wanita & 62 & 64.6 & 64.6 & 100.0 \\
& Total & 96 & 100.0 & 100.0 & \\
\hline
\end{tabular}

Sumber : Data yang diolah SPSS 2020

Karakteristik responden dilihat dari jenis kelamin adalah sebanyak 35,4\% atau 34 orang berjenis kelamin Pria, sebanyak 64,6\% atau 62 orang memiliki jenis kelamin wanita.

\section{b. Responden Menurut Usia}

\section{Karakteristik Responden Berdasarkan Usia}

\begin{tabular}{|c|c|c|c|c|c|}
\hline \multicolumn{6}{|c|}{ Usia } \\
\hline & & Frequency & Percent & Valid Percent & $\begin{array}{c}\text { Cumulative } \\
\text { Percent }\end{array}$ \\
\hline \multirow{6}{*}{ Valid } & $<20$ tahun & 18 & 18.8 & 18.8 & 18.8 \\
\hline & 20-30 tahu & 57 & 59.4 & 59.4 & 79.2 \\
\hline & $31-40$ tahu & 13 & 13.5 & 13.5 & 92.7 \\
\hline & $41-50$ tahu & 7 & 7.3 & 7.3 & 19.8 \\
\hline & $>50$ tahun & 1 & 1.0 & 1.0 & \\
\hline & Total & 96 & 100.0 & 100.0 & \\
\hline
\end{tabular}

Sumber : Data yang diolah SPSS 2020

Karakteristik responden dilihat dari usia adalah sebanyak $18,8 \%$ atau 18 orang berusia $<20$ tahun, sebanyak $59,4 \%$ atau 57 orang berusia sekitar $21-30$ tahun, sebanyak $13,5 \%$ atau 13 orang berusia sekitar $31-40$ tahun, sebanyak $7,3 \%$ atau 7 orang berusia sekitar 41-50 tahun dan 1\% atau >50 tahun sebanyak 1 orang. Seperti yang tertera pada tabel Karakteristik responden dilihat dari usia di atas diketahui bahwa responden terbanyak yang paling sering membeli roti Breadlife Cabang Bintaro Exchangesebagian besar berusia antara 21-30 tahun. 
ISSN NO. (PRINI) 2598-0823, (ONLINE) 2598-2893

c. Responden Berdasarkan Status Pernikahan

Karakteristik Responden Berdasarkan Status Pernikahan Status Pernikahan

\begin{tabular}{|ll|r|r|r|r|}
\hline & Frequency & Percent & Valid Percent & \multicolumn{1}{|c|}{$\begin{array}{c}\text { Cumulative } \\
\text { Percent }\end{array}$} \\
\hline \multirow{2}{*}{ Valid } & Menikah & 49 & 51.0 & 51.0 & 51.0 \\
& Tidak menika & 47 & 49.0 & 49.0 & 100.0 \\
& Total & 96 & 100.0 & 100.0 & \\
\hline
\end{tabular}

Sumber : Data yang diolah SPSS 2020

Karakteristik responden dilihat dari status pernikahan dapat diketahui sekitar $51 \%$ atau 49 orang menikah dan $49 \%$ atau 47 orang belum menikah. Jadi dapat disimpulkan bahwa responden terbanyak yang membeli roti Breadlife Cabang Bintaro Exchange sebagian besar sudah menikah.

d. Responden Berdasarkan Lama Berlangganan

Karakteristik Responden Berdasarkan Lama berlangganan

Lama_berlangganan

\begin{tabular}{|r|r|r|r|r|}
\hline & Frequency & Percent & Valid Percent & $\begin{array}{c}\text { Cumulative } \\
\text { Percent }\end{array}$ \\
\hline \multirow{2}{*}{ Valid $\quad>1$ tahu } & 62 & 64.6 & 64.6 & 64.6 \\
& 34 & 35.4 & 35.4 & 100.0 \\
Total & 96 & 100.0 & 100.0 & \\
\hline
\end{tabular}

Sumber : Data yang diolah SPSS 2020

Karakteristik responden dilihat dari lama berlangganan selama $<1$ tahun berjumlah $64,6 \%$ atau 62 orang dan,selama $>1$ tahun $35,4 \%$ atau 34 orang responden. Seperti yang tertera pada tabel di atas dapat di ketahui bahwa responden terbanyak yang membeli roti Breadlife Cabang Bintaro Exchange sebagian besar kurang dari 1 tahun. 


\section{Hasil Analisis Deskriptif}

\section{a. Store Atmosphere}

\begin{tabular}{|c|c|c|c|c|c|c|c|c|c|c|}
\hline \multirow{2}{*}{ No } & \multirow{2}{*}{ Pernyataan } & \multirow{2}{*}{$\frac{\text { SS }}{5}$} & \multirow{2}{*}{$\begin{array}{l}S \\
4\end{array}$} & \multirow{2}{*}{$\begin{array}{l}\mathrm{N} \\
3\end{array}$} & \multirow{2}{*}{$\begin{array}{l}\text { TS } \\
2\end{array}$} & \multirow{2}{*}{$\frac{\text { STS }}{1}$} & \multirow{2}{*}{ Total } & Total & Rata2 & \multirow{2}{*}{ KET } \\
\hline & & & & & & & & Skor & Skor & \\
\hline \multicolumn{11}{|c|}{ Exterior } \\
\hline 1 & $\begin{array}{l}\text { Papan nama logo } \\
\text { terpampang } \\
\text { dengan jelas dan } \\
\text { memiliki desain } \\
\text { yang menarik }\end{array}$ & 49 & 45 & 2 & 0 & 0 & 96 & 431 & 4.48 & SB \\
\hline 2 & $\begin{array}{l}\text { ukuran toko yang } \\
\text { relatif luas } \\
\text { sehingga } \\
\text { memudahkan } \\
\text { akses masuk ke } \\
\text { dalam toko }\end{array}$ & 25 & 61 & 8 & 2 & 0 & 96 & 397 & 4,13 & B \\
\hline & $\mathbf{F}$ & 74 & 106 & 10 & 2 & 0 & 192 & 828 & 8,61 & \\
\hline & $\%$ & $\begin{array}{c}38,5 \\
4\end{array}$ & $\begin{array}{c}55,2 \\
1\end{array}$ & 5,21 & 1,04 & 0 & 100 & & 4,30 & SB \\
\hline \multicolumn{11}{|c|}{ General Interior } \\
\hline 3 & $\begin{array}{l}\text { Penataan cahaya } \\
\text { di dalam toko } \\
\text { sudah cukup } \\
\text { terang dan jelas }\end{array}$ & 47 & 48 & 0 & 1 & 0 & 96 & 429 & 4.46 & SB \\
\hline 4 & $\begin{array}{l}\text { Sound system/ } \\
\text { Musik di dalam } \\
\text { toko terdengar } \\
\text { tenang (tidak } \\
\text { berisik) dan tidak } \\
\text { menggangggu }\end{array}$ & 39 & 48 & 8 & 1 & 0 & 96 & 413 & 4.30 & SB \\
\hline 5 & $\begin{array}{l}\text { Aroma yang ada } \\
\text { di dalam toko } \\
\text { dapat menarik } \\
\text { konsumen. }\end{array}$ & 42 & 49 & 4 & 1 & 0 & 96 & 420 & 4,37 & SB \\
\hline & $\mathbf{F}$ & 128 & 145 & 12 & 3 & 0 & 288 & 1262 & 13,13 & \\
\hline & $\%$ & 44,4 & 50,4 & 4,16 & 1,04 & 0 & 100 & & 4,37 & SB \\
\hline \multicolumn{11}{|c|}{ Store Layout } \\
\hline 6 & $\begin{array}{l}\text { Arus lalu lintas } \\
\text { didalam toko dan } \\
\text { area kasir } \\
\text { dirasakan cukup } \\
\text { lapang dan } \\
\text { teratur }\end{array}$ & 37 & 53 & 5 & 1 & 0 & 96 & 414 & 4,31 & SB \\
\hline
\end{tabular}


ISSN NO. (PRINT) 2598-0823, (ONLINE) 2598-2893

\begin{tabular}{|c|c|c|c|c|c|c|c|c|c|c|}
\hline 7 & \begin{tabular}{|l} 
Penataan produk \\
roti yang \\
ditampilkan \\
cukup rapi dan \\
menarik. \\
\end{tabular} & 45 & 48 & 0 & 2 & 1 & 96 & 422 & 4.39 & SB \\
\hline 8 & $\begin{array}{l}\text { Produk roti yang } \\
\text { ditawarkan cukup } \\
\text { bervariasi dan } \\
\text { menarik untuk } \\
\text { dibeli }\end{array}$ & 43 & 45 & 8 & 0 & 0 & 96 & 419 & 4.36 & SB \\
\hline & $\mathbf{F}$ & 125 & 146 & 13 & 3 & 1 & 288 & 1255 & 13,06 & \\
\hline & $\%$ & 43,3 & 50.6 & 4,5 & 1,4 & 0,2 & 100 & & 4,35 & SB \\
\hline \multicolumn{11}{|c|}{ Interior Display } \\
\hline 9 & $\begin{array}{l}\text { Gambar dan } \\
\text { poster terlihat } \\
\text { menarik } \\
\text { perhatian }\end{array}$ & 39 & 56 & 1 & 0 & 0 & 96 & 422 & 4.39 & SB \\
\hline 10 & $\begin{array}{l}\text { Dekorasi dinding } \\
\text { terlihat jelas dan } \\
\text { menarik. }\end{array}$ & 31 & 57 & 6 & 0 & 2 & 96 & 403 & 4.19 & B \\
\hline & $\mathbf{F}$ & 70 & 113 & 6 & 0 & 2 & 192 & 825 & 8,58 & \\
\hline & $\%$ & 36,5 & 59 & 3,1 & 0 & 1.04 & 100 & 8,25 & 4,29 & SB \\
\hline & Total Jawaban & 397 & 510 & 42 & 8 & 3 & 960 & & & \\
\hline \multicolumn{2}{|c|}{$\begin{array}{c}\text { Persentase Jawaban } \\
(\%)\end{array}$} & $\begin{array}{c}41,3 \\
6\end{array}$ & 53,1 & 4.4 & 0.83 & 0.31 & 100 & Rata2 & 4,35 & SB \\
\hline
\end{tabular}

Dari tabel di atas diketahui bahwa store atmosphere mendapatkan skor ratarata 4,34 dengan rentang skala 4,20 -5,00 termasuk kriteria Sangat Baik

b. Minat Beli

\begin{tabular}{|c|c|c|c|c|c|c|c|c|c|c|}
\hline \multirow[t]{2}{*}{ No } & \multirow[t]{2}{*}{ Pernyataan } & sS & $\mathbf{S}$ & $\mathbf{N}$ & TS & STS & \multirow[t]{2}{*}{ Total } & Total & Rata2 & \multirow[t]{2}{*}{ KET } \\
\hline & & 5 & 4 & 3 & 2 & 1 & & Skor & Skor & \\
\hline \multicolumn{11}{|c|}{ Minat Transaksional } \\
\hline 1 & $\begin{array}{l}\text { Saya tertarik untuk } \\
\text { membeli roti } \\
\text { Breadlife karena } \\
\text { selalu tersedia } \\
\text { banyak dan } \\
\text { bervariasi }\end{array}$ & 50 & 41 & 5 & 0 & 0 & 96 & 429 & 4.46 & SB \\
\hline 2 & $\begin{array}{l}\text { Saya berminat } \\
\text { membeli produk } \\
\text { roti Breadlife } \\
\text { karena rasanya } \\
\text { yang lebih enak } \\
\text { dibandingkan } \\
\text { produk roti lainnya }\end{array}$ & 23 & 62 & 11 & 0 & 0 & 96 & 396 & 4,12 & B \\
\hline
\end{tabular}




\begin{tabular}{|c|c|c|c|c|c|c|c|c|c|c|}
\hline 3 & $\begin{array}{l}\text { Saya berminat } \\
\text { membeli produk } \\
\text { roti Breadlife } \\
\text { dikarenakan harga } \\
\text { yang relatif murah } \\
\text { berbanding } \\
\text { dengan produk } \\
\text { yang lainnya }\end{array}$ & 42 & 49 & 4 & 1 & 0 & 96 & 420 & 4.37 & SB \\
\hline & $\mathbf{F}$ & 115 & 152 & 20 & 1 & 0 & 288 & 1245 & 12,95 & \\
\hline \multirow{2}{*}{\multicolumn{10}{|c|}{ Minat Referensial }} & SB \\
\hline & & & & & & & & & & \\
\hline 4 & $\begin{array}{l}\text { Saya } \\
\text { merekomendasika } \\
\text { n produk roti } \\
\text { Breadlife kepada } \\
\text { relasi dan kerabat } \\
\text { saya }\end{array}$ & 31 & 58 & 5 & 2 & 0 & 96 & 406 & 4.23 & SB \\
\hline 5 & $\begin{array}{l}\text { Saya berminat } \\
\text { membeli roti } \\
\text { Breadlife karena } \\
\text { promosi dari mulut } \\
\text { ke mulut }\end{array}$ & 36 & 52 & 6 & 2 & 1 & 96 & 410 & 4.27 & SB \\
\hline & $F$ & 67 & 110 & 11 & 4 & 1 & 192 & 816 & 8,5 & \\
\hline & $\%$ & 34,7 & 57,2 & 5,6 & 2,1 & 0,4 & 100 & & 4,25 & SB \\
\hline \multicolumn{11}{|c|}{ Minat Prefensial } \\
\hline 6 & $\begin{array}{l}\text { Saya memilih Roti } \\
\text { Breadlife } \\
\text { dibandingkan } \\
\text { produk roti lain }\end{array}$ & 29 & 59 & 6 & 2 & 0 & 96 & 403 & 4,19 & $B$ \\
\hline 7 & $\begin{array}{l}\text { Produk roti } \\
\text { breadlife bervariasi } \\
\text { dan lebih menarik }\end{array}$ & 41 & 51 & 0 & 3 & 1 & 96 & 416 & 4.33 & SB \\
\hline 8 & $\begin{array}{l}\text { Relasi dan } \\
\text { Kerabat saya lebih } \\
\text { memilih Roti } \\
\text { Breadlife } \\
\text { dibandingkan } \\
\text { produk roti lain }\end{array}$ & 38 & 48 & 9 & 1 & 0 & 96 & 411 & 4.28 & SB \\
\hline & $\mathbf{F}$ & 108 & 158 & 15 & 6 & 1 & 288 & 1230 & 12,8 & \\
\hline & $\%$ & 37,5 & 54,8 & 5,3 & 2,1 & 0,3 & 100 & & 4,26 & SB \\
\hline \multicolumn{11}{|c|}{ Minat Eksploratif } \\
\hline 9 & $\begin{array}{l}\text { Saya mencari } \\
\text { informasi } \\
\text { mengenai produk } \\
\text { roti yang saya } \\
\text { minati }\end{array}$ & 36 & 58 & 2 & 0 & 0 & 96 & 418 & 4.35 & SB \\
\hline
\end{tabular}


ISSN NO. (PRINI) 2598-0823, (ONLINE) 2598-2893

\begin{tabular}{|c|l|c|c|c|c|c|c|c|c|c|}
\hline 10 & $\begin{array}{l}\text { Saya tertarik } \\
\text { untuk membeli } \\
\begin{array}{l}\text { Roti Breadlife } \\
\text { setelah mendapat } \\
\text { informasi dari } \\
\text { teman atau } \\
\text { kerabat }\end{array}\end{array} \quad 31$ & 56 & 7 & 0 & $\mathbf{2}$ & 96 & 402 & $\mathbf{4 . 1 8}$ & $\mathbf{B}$ \\
\hline $\mathbf{F}$ & $\mathbf{6 7}$ & $\mathbf{1 1 4}$ & $\mathbf{9}$ & $\mathbf{0}$ & $\mathbf{2}$ & $\mathbf{1 9 2}$ & $\mathbf{8 2 0}$ & $\mathbf{8 , 5 3}$ & \\
\hline$\%$ & $\mathbf{3 4 , 9}$ & $\mathbf{5 9 . 4}$ & $\mathbf{4 . 7}$ & $\mathbf{0}$ & $\mathbf{1}$ & $\mathbf{1 0 0}$ & & $\mathbf{4 , 2 6}$ & SB \\
\hline Total Jawaban & $\mathbf{3 5 7}$ & $\mathbf{5 3 4}$ & $\mathbf{5 5}$ & $\mathbf{1 1}$ & $\mathbf{3}$ & $\mathbf{9 6 0}$ & & & \\
\hline \hline $\begin{array}{c}\text { Persentase Jawaban } \\
\text { (\%) }\end{array}$ & $\mathbf{3 7 , 2}$ & $\begin{array}{c}\mathbf{5 5 . 6} \\
\mathbf{2}\end{array}$ & $\mathbf{5 . 7 3}$ & $\mathbf{1 . 1 4}$ & $\mathbf{0 . 3 1}$ & $\mathbf{1 0 0 \%}$ & Rata2 & $\mathbf{4 , 2 8}$ & SB \\
\hline
\end{tabular}

Dari tabel di atas diketahui, rata - rata skor Minat Beli adalah 4,28 denan skala interval 4,20-5,00 termasuk dalam kriteria Sangat Baik

3. Analisa Data

a. Uji Validitas

Hasil Uji Validitas Variabel Store Atmosphere (X)

\begin{tabular}{|c|c|c|c|}
\hline \multicolumn{4}{|c|}{ Store Atmosphere $(\mathrm{X})$} \\
\hline No. Kuesioner & R hitung & R tabel & Keterangan \\
\hline 1 & 0.717 & 0,168 & Valid \\
\hline 2 & 0.668 & 0,168 & Valid \\
\hline 3 & 0.631 & 0,168 & Valid \\
\hline 4 & 0.761 & 0,168 & Valid \\
\hline 5 & 0.745 & 0,168 & Valid \\
\hline 6 & 0.588 & 0,168 & Valid \\
\hline 7 & 0.557 & 0,168 & Valid \\
\hline 8 & 0.778 & 0,168 & Valid \\
\hline 9 & 0.769 & 0,168 & Valid \\
\hline 10 & 0.528 & 0,168 & Valid \\
\hline
\end{tabular}

Sumber : Data hasil pengolahan SPSS versi 21.

Hasil Uji Validitas Variabel Minat Beli (Y)

Minat Beli Konsumen (Y)

\begin{tabular}{|c|c|c|c|}
\hline \multicolumn{4}{|c|}{ Minat Beli Konsumen (Y) } \\
\hline No. Kuesioner & R hitung & R tabel & Keterangan \\
\hline 1 & 0.676 & 0.168 & Valid \\
\hline 2 & 0.550 & 0.168 & Valid \\
\hline 3 & 0.562 & 0.168 & Valid \\
\hline 4 & 0.644 & 0.168 & Valid \\
\hline 5 & 0.608 & 0.168 & Valid \\
\hline 6 & 0.467 & 0.168 & Valid \\
\hline 7 & 0.448 & 0.168 & Valid \\
\hline 8 & 0.647 & 0.168 & Valid \\
\hline 9 & 0.681 & 0.168 & Valid \\
\hline 10 & 0.513 & 0.168 & Valid \\
\hline
\end{tabular}

Sumber : Data hasil pengolahan SPSS versi 21. 
Berdasarkan Table Hasil Uji Validitas Store Atmosphere (X) dan Minat beli (Y) diatas diketahui nilai $r_{\text {hitung }}$ memiliki nilai yang lebih besar dari $r_{\text {tabel }}$, dan kesimpulannya bahwa seluruh pertanyaan adalah Valid karena $r_{\text {hitung }}>r_{\text {tabel. }}$

\section{b. Uji Reliabilitas}

Uji reliabilitas dalam riset ini menggunakan Alpha-Cronbach method dengan aplikasi SPSS 21. Dari hasil uji dengan SPSS 21 maka diperolehhasilnya sebagai berikut :

Hasil Uji Reliabilitas

\begin{tabular}{|c|l|c|c|c|}
\hline No & \multicolumn{1}{|c|}{ Variabel } & AlphaCronbach & Syarat & Keterangan \\
\hline 1 & Store Atmosphere (X) & 0.763 & 0.600 & Reliabel \\
\hline 2 & Minat Beli (Y) & 0.741 & 0.600 & Reliabel \\
\hline
\end{tabular}

Sumber : Data Pengolahan SPSS versi 21

\section{c. Uji Regresi Linier Sederhana}

Uji Regresi Linier Sederhana dengan SPSS Versi 21 adalah sebagai berikut :

\section{Hasil Uji Regresi Linier Sederhana}

Coefficients $^{a}$

\begin{tabular}{|c|c|c|c|c|c|}
\hline \multirow[t]{2}{*}{ Model } & \multicolumn{2}{|c|}{$\begin{array}{l}\text { Unstandardized } \\
\text { Coefficients }\end{array}$} & $\begin{array}{l}\text { Standardized } \\
\text { Coefficients }\end{array}$ & \multirow[t]{2}{*}{$t$} & \multirow[t]{2}{*}{ Sig. } \\
\hline & $B$ & Std. Error & Beta & & \\
\hline (Constant) & 9.885 & 2.063 & & 4.790 & .000 \\
\hline $\begin{array}{l}\text { Store_Atmospher } \\
\text { e }\end{array}$ & .758 & .047 & .856 & 16.036 & .000 \\
\hline
\end{tabular}

a. Dependent Variable: Minat_Beli

Sumber : Hasil olahan data SPSS Versi 21

Dari hasil tabel diatas dapat dilihat "a" berada pada Constant dengan perolehan angka 9,885 dan "b" berada pada store atmosphere dengan perolehan angka 0,758

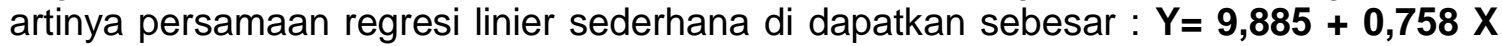
dapat diinterpretasikan sebagai berikut:

1) Dari hasil pengujian maka diperoleh angka persamaan $Y=9,885+0,758$ (X) dimana setiap perubahan $Y$ akan searah dengan perubahan $X$ dan nilai $Y$ akan naik apabila $X$ naik, sebaliknya nilai $Y$ akan turun apabila nilai $X$ turun. Jadi dapat disimpulkan bahwa store atmosphere berpengaruh positif terhadap minat beli konsumen.

2) Disimpulkan berdasarkan persamaan regresi di atas yaitu jika store atmosphere bertambah 1, maka nilai rata - rata minat beli konsumen setiap bulan meningkat sebesar 0,758 atau setiap store atmosphere bertambah 10, maka nilai rata - rata Minat beli setiap bulan meningkat sebesar 7,58 


\section{d. Uji Koefisien Korelasi Product Moment}

Hasil Uji Koefisien Korelasi product menggunakanSPSS Versi 21 adalah sebagai berikut:

\section{Hasil Uji Koefesien Korelasi}

Model Summary

\begin{tabular}{|l|r|r|r|r|}
\hline Model & \multicolumn{1}{|c|}{$\mathrm{R}$} & $\mathrm{R}$ Square & Adjusted R Square & $\begin{array}{c}\text { Std. Error of the } \\
\text { Estimate }\end{array}$ \\
\hline 1 & $.856^{\mathrm{a}}$ & .732 & .729 & 1.924 \\
\hline
\end{tabular}

a. Predictors: (Constant), Store_Atmosphere

Sumber : Hasil olahan data SPSS Versi 21

Dari hasil perhitungan koefisien korelasi pearson didapat hasil koefesien korelasi Rxy sebesar 0,856 dimana berarti terdapat hubungan yang Sangat Kuat antara store atmosphere terhadap minat beli konsumen dikarenakan nilai 0, 856 terletak diantara nilai koefisien korelasi $0,800-1,099$.

\section{e. Uji Koefisien Determinasi}

Determination Coefficient $\left(\mathrm{R}^{2}\right)$ dilakukan untuk mengetahui prosentase pengaruh variabel independen terhadap variabel dependen

\section{Hasil Uji Koefesien Determinasi Model Summary}

\begin{tabular}{|l|r|r|r|r|}
\hline Model & \multicolumn{1}{|c|}{$\mathrm{R}$} & $\mathrm{R}$ Square & Adjusted R Square & $\begin{array}{c}\text { Std. Error of the } \\
\text { Estimate }\end{array}$ \\
\hline 1 & $.856^{\mathrm{a}}$ & .732 & .729 & 1.924 \\
\hline
\end{tabular}

a. Predictors: (Constant), Store_Atmosphere

Sumber : Hasil olahan data SPSS Versi 21

Dari hasil uji statistic diketahui bahawa determination coefficient ( $R$ Square)yang diperoleh sebesar 0.732. artinya store atmosphere memiliki pengaruh terhadap minat beli konsumen sebesar $73.2 \%$ dan dipengaruhi oleh variabel-variabel lain yang tidak diteliti sebesar $26,8 \%$.

\section{f. Uji Hipotesis (Uji t)}

Hasil Uji Hipotesis / Uji t

Coefficients $^{a}$

\begin{tabular}{|c|c|c|c|c|c|}
\hline \multirow[t]{2}{*}{ Model } & \multicolumn{2}{|c|}{$\begin{array}{c}\text { Unstandardized } \\
\text { Coefficients }\end{array}$} & $\begin{array}{l}\text { Standardized } \\
\text { Coefficients }\end{array}$ & \multirow[t]{2}{*}{$\mathrm{t}$} & \multirow[t]{2}{*}{ Sig. } \\
\hline & $B$ & Std. Error & Beta & & \\
\hline $\begin{array}{ll}1 & \text { (Constant) } \\
& \text { Store_Atmosphere }\end{array}$ & $\begin{array}{r}9.885 \\
.758\end{array}$ & $\begin{array}{r}2.063 \\
.047\end{array}$ & .856 & $\begin{array}{r}4.790 \\
16.036\end{array}$ & $\begin{array}{l}.000 \\
.000\end{array}$ \\
\hline
\end{tabular}

a. Dependent Variable: Minat_Beli

Sumber : Hasil olahan data SPSS Versi 21 
Diketahui dari tabel 4.19 diatas, besarnya $t$ tabel adalah 1,6612 dilihat dari $t$ tabel dengan df : $96-2=94$. dari tabel 4.19 diketahui $t$ hitung $>t$ tabel yaitu sebesar $4,790>$ 1,6612, hal ini dikatakan positif dengan nilai signifikansi $0,000<0,1$. dimana berarti $\mathrm{H}_{0}$ ditolak dan $\mathrm{H}_{1}$ diterima, ada pengaruh yang positif dan signifikan antara store atmosphere terhadap minat beli konsumen

\section{E. KESIMPULAN}

Jadi penulis memberikan kesimpulan dari hasil anilisis dan pembahasan yang telah diuraikan di atas adalah sebagai berikut :

1. Store Atmosphere padapada Toko Roti Breadlife Cabang Bintaro Exchangedari 10 pertanyaan dengan jumlah 96 responden, dengan skor rata-rata 4,34 dengan rentang skala 4,20 -5,00 termasuk kriteria Sangat Baik.Hal ini diketahui dari jawaban responden pada butir pernyataan" padageneral interior yaitu pencahayaan yang ada di dalam toko sudah cukup terang, Suara/musik yang ada di dalam toko terdengar tenang (tidak berisik) dan Aroma yang ada di dalam toko dapat menarik konsumen.

2. Minat beli konsumen pada pada PT Dunia Makmur Jaya Tbk Cabang Bintaro Exchange,dari 10 pertanyaan dengan jumlah 96 responden, dengan skor rata - rata 4,28 dengan rentang skala 4,20-5,00 termasuk kriteria Sangat Baik.Hal ini terlihat dari jawaban responden pada butir pernyataan" padaminat transaksional yaitu konsumen tertarik untuk membeli roti Breadlife karena selalu tersedia banyak, produk roti Breadlife karena rasanya yang lebih enak dibandingkan produk roti lainnya dan harganya relatif murah dibandingkan dengan produk lainnya.

3. Adanya pengaruh positif dan signifikan antara store atmosphere terhadap minat beli konsumen dengan diperoleh persamaan regresi $\mathbf{Y}=\mathbf{9 , 8 8 5}+\mathbf{0 , 7 5 8} X$ diartikan bahwa apabila nanti store atmosphere bertambah 1, nilai rata - rata minat beli tiap bulan bertambah sebesar 0,758 atau setiap nilai store atmosphere bertambah 10, maka nilai rata - rata minat beli tiap bulan bertambah pula sebesar 7,58. Besarnya Koefisien korelasi $(\mathrm{R})$ yaitu $\mathbf{0 , 8 5 6}$, menunjukkan store atmosphere $(\mathrm{X})$ memiliki tingkat kekuatan pengaruh yang sangat kuat terhadap minat beli $(\mathrm{Y})$. Koefisien determination $(R$ Square)yang diperoleh sebesar 0.732 menunjukkan store atmosphare mempengaruhi minat beli sebesar $73,2 \%$ dan sisanya $\mathbf{2 6 , 8} \%$ dipengaruhi oleh variabel-variabel lain yang tidak diteliti. Uji hipotesis diperoleh dengan membandingkan $t$ hitung $>t$ tabel yaitu sebesar $4,790>1,6612$, hal ini dikatakan positif dan diperkuat dengan nilai signifikansi $\mathbf{0 , 0 0 0}<\mathbf{0 , 1}$. Artinya $\mathrm{H}_{0}$ ditolak dan $\mathrm{H}_{1}$ diterima, terdapat pengaruh yang positif dan signifikan antara store atmosphrereterhadap minat beli.

\section{DAFTAR PUSTAKA}

Adi, Ignatius Venta Wijaya. (2015). Pengaruh Suasana Toko (Store Atmosphere) dan lokasi terhadap Minat Beli Konsumen (Studi Kasus pada Distro KoffinStore di Yogyakarta). Skripsi. Yogyakarta : Universitas Sanata Dharma

Arikunto, Suharsimi. (2012). Prosedur Penelitian Suatu Pendekatan Praktik. Jakarta : Rineka Cipta

Ariyanto, Noval M, dkk. (2016). Pengaruh Store Atmosphere dan Atribut Produk terhadap Minat Beli Konsumen (Studi Kasus Rumah Makan Ayam Bakar Wong Solo cab. 
Jember) Vol, 2, No. 1, Edisi Juni 2016. No. ISSN : 2460-9471. Jurnal. Jember : Universitas Muhammadiyah

Berman, Barry and Joel R. Evans. (2014). Retail Management (dialih bahasakan oleh Lina Salim) 12th Edition. Jakarta : Pearson

Kingdom : Pearson

(2017). Retail Management: A Retail Approach. United

Buchari, Alma. (2012). Manajemen Pemasaran dan Pemasaran Jasa. Bandung : CV. Alfabeta

Bukhani, Z. T., \& Lesmana, R. (2020). Analisis Faktor Normatif Dan Informatif Pemasaran Terhadap Keputusan Pembelian Konsumen Pada Supermarket Yogya Kota Kuningan Jawa Barat. Jurnal Pemasaran Kompetitif, 1(4).

Ghozali, Imam. (2013). Aplikasi Analisis Multivariate dengan Program IBM SPSS 21 Update PLS Regresi. Semarang: Badan Penerbit UniversitasDiponegoro.

Handoko, Hani T. (2013). Manajemen. Edisi 2. Yogyakarta : BPPE

Hasibuan, Malayu, S.P. (2012). Manajemen Sumber Daya Manusia. Jakarta: PT Bumi Aksara

(2013). Manajemen Sumber Daya Manusia. Jakarta: PT Bumi Aksara

Julianti, Ni Luh, Made Nuridja \& Made Ary Metriana. (2014). Pengaruh Store Atmosphere terhadap Minat Beli Konsumen pada Toserba Nusa Permai di Kecamatan Nusa Penida. Jurnal Pendidikan Ekonomi Undiksha,Vol 4 No. 1

Kotler, Philip \& Gary Amstrong. (2015). Priciples of Marketing. 15e Global Edition. Pearson

Kotler, Philip and Kevin Lane Keller. (2012). Marketing Management, Edisi 14, New Jersey: Prentice-Hall Published

Kotler, Philip and Kevin Lane Keller. (2016). Marketing Management, 15th Edition, Pearson Education, Inc.

Lamb. (2012). Manajemen Pemasaran (dialih bahasakan oleh Bob Sabran). Jakarta : Erlangga

Lesmana, R. (2017). Pengaruh Citra Perusahaan Terhadap Keputusan Pembelian Konsumen PT. Garuda Indonesia Tbk.(Persero). JIMF (Jurnal IImiah Manajemen Forkamma), 1(1).

Lesmana, R. (2016). Strategi Pemasaran untuk Meningkatkan Penjualan Perumahan di Green River City Bekasi (Studi Kasus di PT. Artha Bangun Pratama). INOVASI Jurnal IImiah IImu Manajemen, 3(2), 40-59.

Lesmana, R., \& Hasbiyah, W. (2019). Model Analisis Kepuasan dan Loyalitas Wisatawan Lokal Studi Kasus pada Objek Wisata Kepulauan Seribu Jakarta. JIMF (Jurnal IImiah Manajemen Forkamma), 2(3). 
Lesmana, R. (2015). analisis strategi pemasaran untuk meningkatkan penjualan perumahan green river city bekasi (study kasus di pt. artha bangun pratama) (Doctoral dissertation, Universitas Pamulang).

Meldarianda, Resti dan Hengky Lisan. (2010). Pengaruh Store Atmosphere terhadap Minatbeli Konsumen pada Resort Café Atmosphere Bandung. Jurnal Bisnis Ekonomi (JBE) Vol 17 No. 2, 97-108

Oentoro, Deliyanti. (2010) Manajemen Pemasaran Modern. Edisi 12, Yogyakarta : LaksBang PRESSindo

Siagian, S.P. (2018). Manajemen Sumber Daya Manusia. Jakarta: Bumi Aksara

Sudjana. (2011). Metode Statistika. Bandung : Tarsito.ng

Sugiono. (2015). Metode Penelitian Kuantitatif, Kualitatif dan $R$ \& D, Edisi Cetakan Dua Puluh Dua. Bandung: CV Alfabeta , (2016). Metodologi Penelitian Kuantitatif, Kualitatif, dan R\&D. Bandung: CV Alfabeta

Supangat, Andi. (2010). Statistik Dalam Kajian Deskriptif, Inferensi, dan Nonparametrik. Jakarta : Kencana Prenada Media Group.

Sutarman, A., \& Lesmana, R. (2019, January). Analisis Keputusan Pembelian Konsumen dari Sisi Normtif dan Informatif Pada Supermarket Giant Pamulang, Tangerang Selatan. In PROCEEDINGS (Vol. 1, No. 1).

Tjiptiono, Fandy dan Gregorius Chandra. (2012). Pemasaran Strategik. Yogyakarta : CV. Andi Offset

Tjiptono, Fandy. (2015).Strategi Pemasaran. Yogyakarta : CV. Andi Offset

Utami, Chrsitina Widya. (2017). Manajemen Ritel Edisi 3. Jakarta : Salemba Empat

Veronika. (2016). Pengaruh Iklan dan Brand Image terhadap Minat Beli Konsumen, dengan Minta Beli sebagai Variabel Mediasi. Skripsi. Yogyakarta : Universitas Sanata Dharma

Widiastuti, Okta. (2017). Hubungan antara Persepsi terhadap Kualitas Produk dengan Minat beli Bedak Muka Sariayu pada Mahasiswi di Universitas Mercubuana Yogyakarta . Skripsi thesis. Yogyakarta : Universitas Mercubuana

Wulandari, Dian Pertiwi dan Maya Arianti. (2019). Pengaruh Store Atmosphere terhadap Minat Beli Konsumen pada Sejiwa Coffee.Jurnal Mitra Manajemen, Vol 3 No. 1, 5771 